\title{
An Overview of the Factors Affecting the Migration of Sturgeons in Yeşilırmak
}

\author{
Serap Ustaoğlu Tırıl' (D), Devrim Memiş² (D)
}

Cite this article as: Ustaoğlu Tirıl, S., Memiş, D. (2018). An Overview of the Factors Affecting the Migration of Sturgeons in Yeşilırmak. Aquatic Sciences and Engineering, 33(4): 138-144.

Ustaoğlu Tırıl S, Memiș D., 2016. An Overview of the Factors Affecting the Migration of Sturgeons in

Yeşilırmak River. Workshop on Fish Passages and Migration, istanbul University Fisheries Faculty 21-22 November 2016, istanbul, Turkey, Abstracts Book: 49-50.

'Sinop University, Faculty of Fisheries, Sinop, Turkey

2'stanbul University, Faculty of Aquatic Science, İstanbul, Turkey

Submitted:

12.07.2018

Accepted:

08.10.2018

Correspondence:

Serap Ustaoğlu Tırıl

E-mail:

serapt@sinop.edu.tr

(C) Copyright 2018 by Aquatic

Sciences and Engineering

Available online at

ase.istanbul.edu.tr

\section{ABSTRACT}

The Yeşilırmak is one of the rivers in Turkey where sturgeons migrate for spawning. It originates in the Kösedağ Mountains in Sivas and flows into the Black Sea at the plain of Çarşamba. The Yeşilırmak plays a major role in agricultural production and irrigation, and it also supplies energy due to the hydroelectric power plant (HPP). Serious structural changes and significant habitat loss for sturgeons and other fish species have occurred due to the dams and HPPs in the Yeşilırmak, especially since the 1970s. It is also a known fact that fish passages in these constructions are not suitable for the sturgeons to pass through. Unfortunately, coastal regulations along the river have had a negative effect on the habitats. Although the Yeşilırmak has lost quite a lot of its natural structure and its waterway gradually shortened due to the HPPs, sturgeons can still migrate upstream into it. Therefore, related sectors and stakeholders should consider the importance of the Yeşilırmak in their planned activities for the future of sturgeons in Turkish waters. In this study, the major factors affecting the sturgeon migration in the Yeşilırmak will be evaluated.

Keywords: Yeşilırmak, sturgeon, dam, hydroelectric power plant

\section{INTRODUCTION}

Many fish species in the world are facing the danger of extinction due to various activities in their living and breeding ground which lead to habitat loss and pollution, in addition to manmade causes such as illegal and/or overfishing which are also responsible for their extinction. Due to these reasons, almost all species of sturgeon, which are of great importance due to the black caviar, now considered as "a symbol of luxury and high status" worldwide, are categorized by the IUCN (International Union for Conservation of Nature) in the red list of threatened animals as CR (critically endangered): species facing an extremely high risk of extinction in the wild (Anonymous, 2018a).

Sturgeons have existed for about 200 million years and are referred to as "living fossils" (Kirschbaum and Gessner, 2001). It is understood from the historical records that sturgeons were captured in Dniester in the 2500s BC, served with decorations in the great celebrations and printed money bore pictures of them. It is also reported that sturgeon caviar is of great political interest and wars were caused due to caviar (Reichle, 1997). From the 20 $0^{\text {th }}$ century, sturgeon began to be overfished worldwide. However, from the 1960s, due to the construction of dams, HPP (Hydroelectric Power Plant) and flood control sets on the spawning rivers began to lose spawning areas. At the same time, the destruction of spawning grounds, eggs and larvae due to the removal of sand and gravel from the rivers has also played a role in the decline of stocks. Agrochemicals, domestic and industrial wastes contaminated rivers which increased the destruction of spawning areas (Hochleithner, 1996). Since the same adverse conditions are still present despite some measures such as sturgeon fishing ban and stock enhancement, there is no improve- 
ment in the critical situation of sturgeons. Five sturgeon species (Acipenser gueldenstaedtii, Acipenser nudiventris, Acipenser stellatus, Acipenser sturio and Huso huso) are naturally found in the Turkish waters and these species migrate into the large rivers (e.g. Sakarya, Yeşilımak, Kızılırmak) to spawn. In addition, until the 1970s sturgeon fishing was economically important in Turkish fishery and was known to have an important share in fishing activities especially in Çarşamba, Bafra, Karasu and Istanbul (Anonymous, 2015b). In 1989, FAO (Food and Agriculture Organization of the United Nations) experts reported that A. sturio, H. huso, A. gueldenstaedtii, A. stellatus and $A$. nudiventris were found in the fishing ports of the Turkish coast and the most common species of sturgeons were A. sturio and $\mathrm{H}$. huso (Edwards and Doroshov, 1989). But in recent years the situation has completely changed and sturgeons are at the brink of extinction in Turkish waters. It is known that over-fishing, construction of dams and HPPs, flood control sets and pollution in rivers played a very significant role in this situation (Anonymous, 2015b).

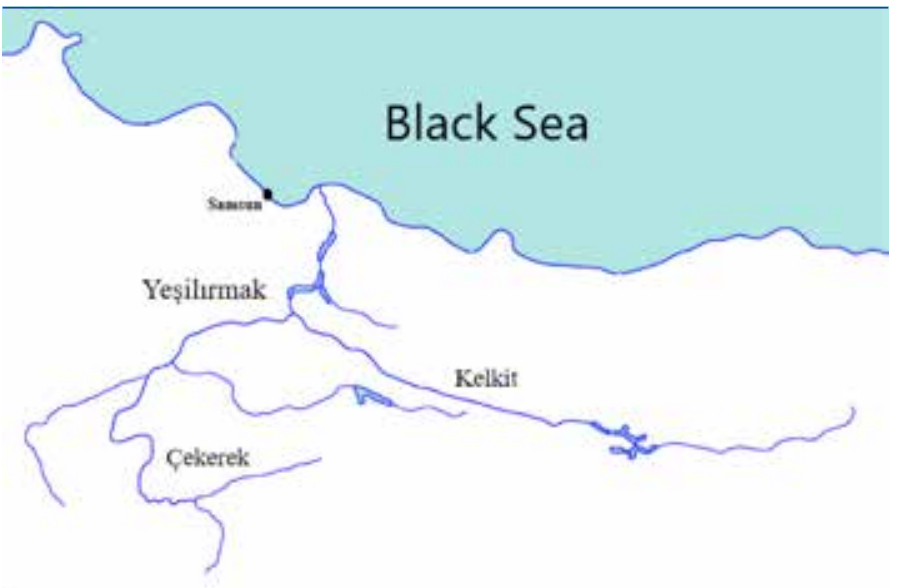

Figure 1. Yeşilırmak

\section{The Importance of Yeşilırmak for Sturgeons and the Effects of Hydroelectric Power Plants}

Yeşilırmak is 519 km long and is derived from Kösedağ located within the boundaries of Sivas Province and flow into the Black Sea in Samsun-Çarşamba (Figure 1). While passing through Tokat, Amasya and Samsun, it connects with Çekerek, Tersakan and Kelkit Streams.

Yeşilırmak, streams and brooks located in the west and east of the Yeşilırmak spilled into the sea individually, formed Yeşilırmak river basin which is one of the 25 river basins of Turkey (Figure 2). The Yeşilırmak Basin (Number 14) contains all and/or parts of Tokat, Samsun, Amasya, Çorum, Sivas, Yozgat, Gümüşhane, Giresun, Erzincan, Ordu and Bayburt. Yeşilırmak River Basin, covering approximately $5 \%$ of the surface area of Turkey, which is the third largest precipitation area covers an area of $39628 \mathrm{~km}^{2}$ of the country. Silts carried by Yeşilırmak and its branches forms the Çarşamba Plain (Anonymous, 2015a).

Yeşilırmak is a meandering river and forms the fertile Çarşamba Plain. Çarşamba Plain is a delta plain in the Central Black Sea Region. There is Çaltı Cape on the eastern end and Cıva Cape on the western end of the plain. There are shallow lakes, marshes and lagoons in the north side of the plain. Yeşilırmak, which flows from the Civa Cape to the Black Sea, plays an important role in the formation of Çarşamba Plain, has an important role in the agricultural potential of the region (Kadıoğlu, 2016).

Moreover, along with the contribution in the agricultural production of Turkey, Yeşilırmak also plays an important role in the electricity production. There are 21 dams and/or HPPs for irrigation and electricity production on Yeşilırmak, which made an irregular flow regime of the river. HPPs in Yeşilırmak has a total capacity of $887 \mathrm{MW}$, which meets approximately $3.4 \%$ of the total electricity produced from HPPs in Turkey (Table 1) (Anonymous, 2018b). Hasan Ugurlu and Suat Ugurlu dams, Kumköy HPP and Çarşamba HPP are the closest to the mouth of the Yeşilırmak in Samsun.

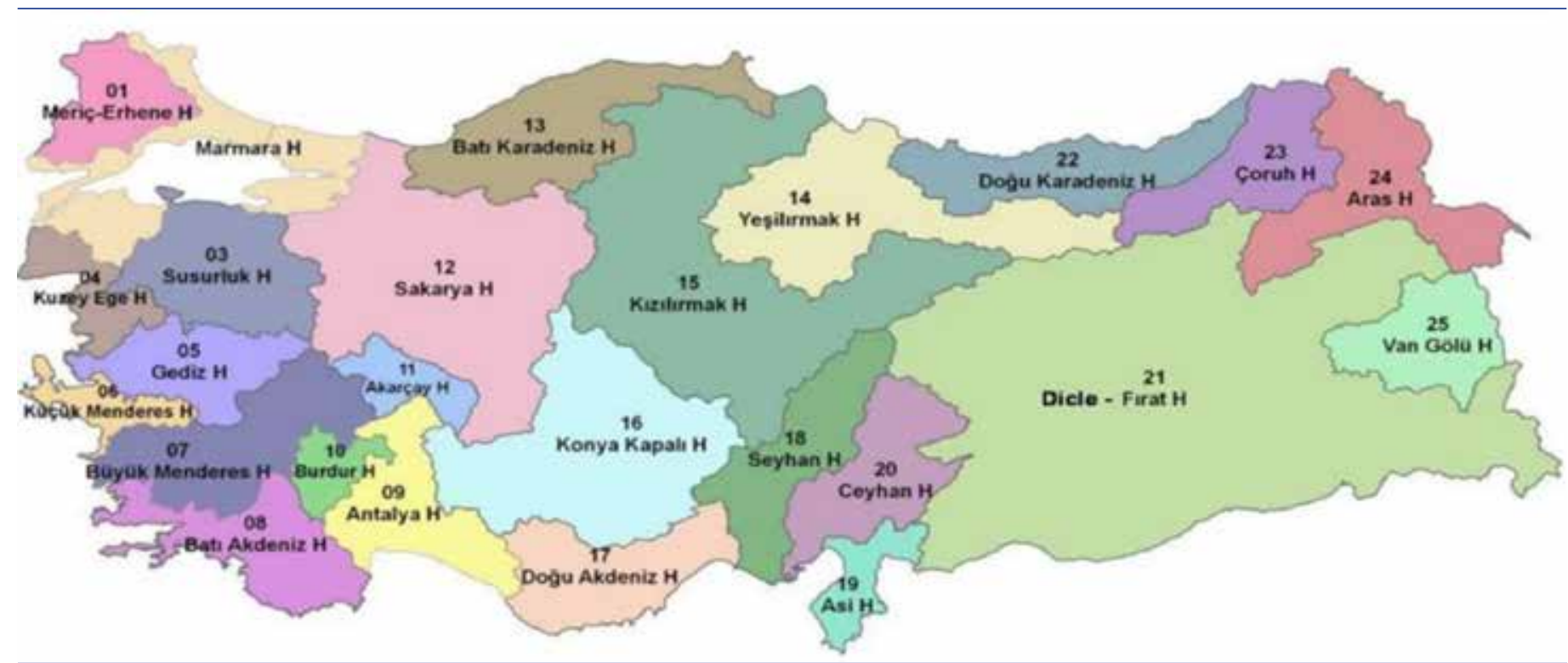

Figure 2. River Basin Map of Turkey (National Watershed Management Strategy (2014-2023) - (07/04/2014 date and 29050 numbered Official Newspaper) 
Besides its role in the supply of agricultural product and demand of electricity, Yeşilırmak has vital importance for sturgeons, which is very valuable for the biodiversity of the world as well as Turkey. Considering the history of sturgeons in the Turkish waters, sturgeon used to spawning in Samsun, the meeting point of two rivers (Yeşilırmak and Kızılırmak Rivers) with the Black Sea. Until the 1970s, sturgeons were caught in Kızılırmak, Yeşilırmak and Sakarya Rivers and their estuary, and about 8 tons of caviar were produced annually. Caviar industry which was seen as an important source of income for the economy of Turkey, was reported in the "Second Industrial Plan of the Republic of Turkey-1936" and considered worthy for support as being an important branch of industry that had to be improved. In the industrial plan, it was reported that caviar was mostly obtained from $H$. huso in the 1930's, and sturgeons were captured mostly in Sakarya, Kızılırmak and Yeşilırmak, especially around Bafra district in Samsun province. In this plan, it was also reported that more than 2000 sturgeons per year were caught by hook (in Turkish: karmak) in the river estuaries, half of them were mature enough to produce caviar and caviar production reached 4 tons per year. According to the FAO report, prepared by Edward and Doroshov (1989), caviar production was about 8 tons/year between 1940-1970 around Samsun (Ustaoğlu Tırıl and Memiş, 2015).

Besides the Second Industrial Plan of the Republic of Turkey-1939, the above-mentioned FAO report and a few research articles, there are many newspaper articles and other materials e.g. photos and videos which can be considered as important evidences of the presence of sturgeons and their status in the Turkish rivers. The newspaper article in Figure 3 ("This fish is another fish") is one of the most striking examples on this issue. According to this article, at the end of the 1960's, beluga ( $H$. huso), ship sturgeon ( $A$. nudiventris) and other species (A. gueldenstaedtii, A. sturio or A. stellatus) were caught in the mouths of Kızılırmak and Yeşilırmak and caviar trade was a major source of income for many families in Bafra and Çarşamba distritcts (Hayat Magazine, 1969).

Similar information was found in the Second Industrial Plan of the Republic of Turkey (1939) where it was reported that sturgeon catch and caviar production did not develop enough in those years. It was also reported that the main reason was that the mature sturgeons could not enter the river to spawn due to the logs in the mouth of the rivers (Sakarya, Kızılırmak and Yeşilırmak). It is also understood that the obstacles in sturgeon spawning habitats were not HPPs in those years, on the contrary, the drifted and accumulated logs in the river mouths. It was also suggested in this Plan that these natural obstacles must be cleaned before the spawning season and this should be done regularly. Nowadays, it is known that sturgeons can still enter the rivers, but could not pass through the dam or HPP and was caught under the dam or HPP. (Ustaoğlu Tırıl and Memiş, 2013, Ustaoğlu Tırıl and Memiş, 2015).

Table 1. Dams and HPPs on Yeşilırmak (Anonymous, 2018b).

\begin{tabular}{|c|c|c|}
\hline Dam/HPP Name & Province/District & Installed capacity (MW) \\
\hline Hasan Uğurlu Dam and HPP & Samsun, Ayvacık & 500 \\
\hline Suat Uğurlu Dam and HPP & Samsun, Çarşamba & 69 \\
\hline Çarşamba HPP & Samsun, Çarşamba & 11 \\
\hline Almus Dam and HPP & Tokat, Almus & 27 \\
\hline Çilehane HPP & Tokat, Almus ve Reşadiye & 7 \\
\hline Köklüce HPP & Tokat, Niksar & 90 \\
\hline Yeşilırmak 1 HPP & Tokat, Reşadiye & 14 \\
\hline Yeşilırmak 2 Regulator and HPP & Tokat, Reşadiye & 6 \\
\hline Amasya Kale HPP & Amasya, Merkez ve Taşova & 29 \\
\hline Midilli HPP & Amasya, Merkez ve Taşova & 33 \\
\hline Yavuz HPP & Amasya, Taşova & 23 \\
\hline Umutlu HPP & Amasya, Taşova & 20 \\
\hline Osmancık HPP & Amasya & 9 \\
\hline Taşova Yenidereköy HPP & Amasya, Taşova & 2 \\
\hline Karayel HPP (with production license) & Amasya, Taşova & 22 \\
\hline Yeşil HPP & Sivas & 14 \\
\hline
\end{tabular}


Although the habitat structure and flow regime of Yeşilırmak are quite different from its natural structure, it is reported that the mature sturgeons, especially $H$. huso, migrate to Yeşilırmak (Zengin and Ustaoğlu Tırıl, 2012). In this regard, the latest data in Yeşilırmak was reported on 11 March 2012. A Huso huso, weighed $150 \mathrm{~kg}$, was caught by the local people in a puddle of the river bed in Yeşilırmak, nearly $20 \mathrm{~km}$ far from the Yeşilırmak river mouth. It was a female fish and $20 \mathrm{~kg}$ of caviar was obtained from it. This data demonstrates that the sturgeons still migrate to Yeşilırmak (Ustaoğlu Tırıl and Memiş, 2013). Therefore, the part from the Yeşilırmak river mouth to the first HPP (Çarşamba HPP) is very important for the spawning migration of sturgeons.

The habitat of sturgeons in Yeşilırmak was evaluated in one of the studies which was done as a project entitled "Recovery of Sturgeon Population in Turkey: Habitat Assessment and Restocking" supported by the Food and Agriculture Organization of the United Nations (FAO) and coordinated by the Ministry of Agriculture and Rural Affairs of Turkey (MARA). In this study, the area from Suat Uğurlu Dam to the river mouth of Yeşilırmak was evaluated and determined that the construction of Kumköy HPP and Çarşamba HPP caused significant loss of spawning and feeding habitat for sturgeon. In the National Action Plan prepared at the end of this project was high-

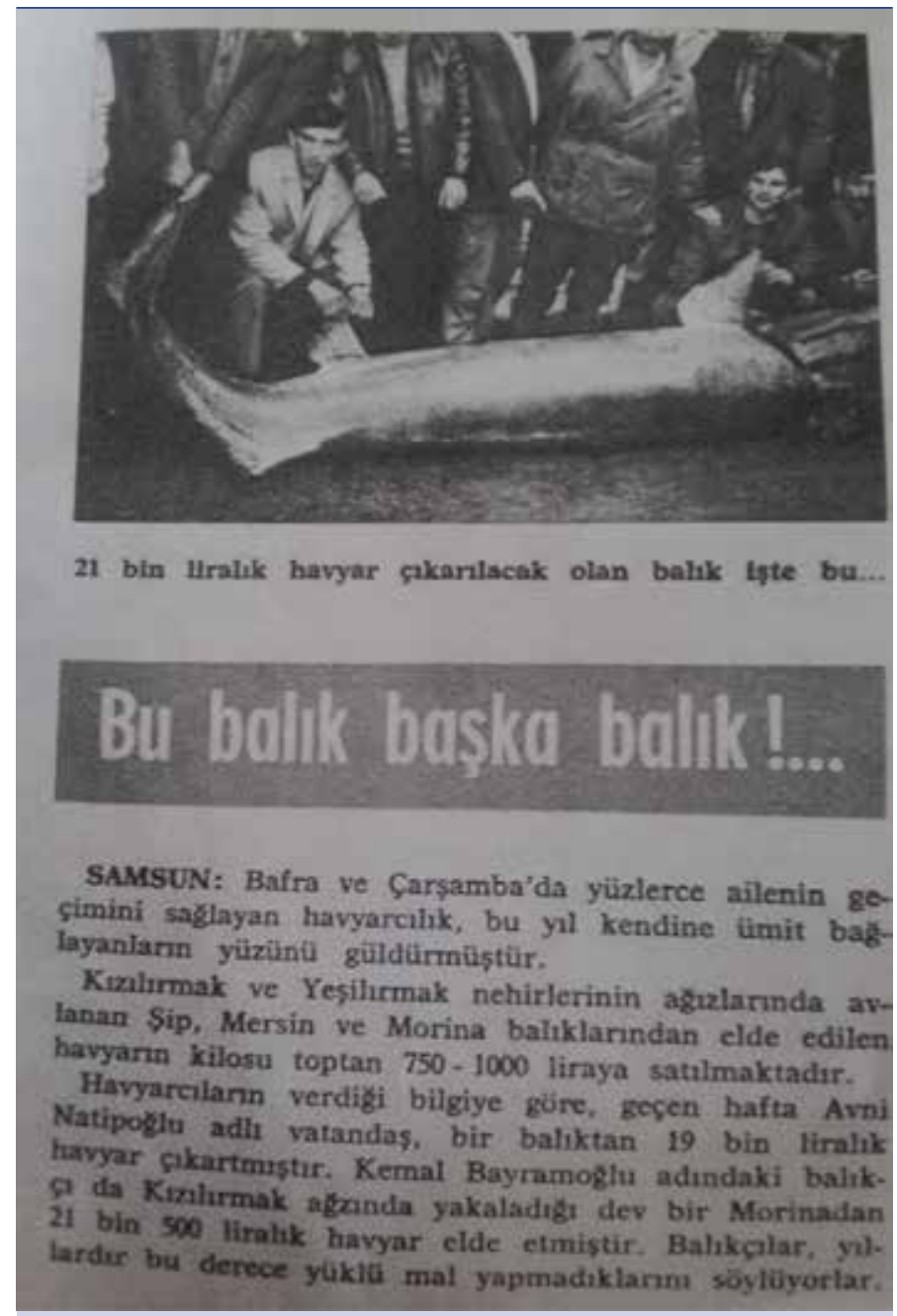

Figure 3. Newspaper article in Hayat Magazine (29.05.1969) lighted to the critical status of sturgeons in Yeşilırmak in terms of habitat loss. In this Plan, it was also reported that serious rehabilitation studies are urgently needed in Yeşilırmak (Anonymous, 2015b). There are successful studies (Hayes and Caroffino, 2012; Hall et al., 2012; Gessner et al., 2014) for the rehabilitation and restoration of sturgeon habitats in different countries such as Germany, Romania, USA and Canada. It should be urgently assessed whether similar rehabilitation and restoration studies can be carried out in Turkey.

\section{Threats to Sturgeons in Yeşilırmak}

\section{Fisheries on the River Mouth}

Estuaries are among the most productive natural habitats in the world in terms of biological productivity due to the rich nutrients transported from the river and accumulated on the river bed. Throughout history, estuaries are important for human settlement and transportation, but today the estuaries are mostly under threat from human activities such as domestic and industrial wastes, shipping and fisheries activities. Despite all the negativity, estuaries give a fascinating insight in the natural habitat, where energy is transformed from sunlight into plant material and then through the steps of a food chain is converted into a rich food supply for fish and birds. Estuaries are important nursery and feeding areas for many fish species because of their high biological productivity. At the same time, these are the important areas for the migration routes of anadromous and catadromous fish species (McLusky and Elliot, 2011).

As in many estuaries in Turkey, the commercial fisheries on the mouth of Yeşilırmak is one of the most important economic income sources for the local people. It is known that during these fishing activities in this region, sturgeons are also caught occasionally together with another fish species. Therefore, commercial fisheries are a significant threat to the sturgeons in this region and special protection strategies (e.g. strictly control or complete fishing ban) should be determined in order to prevent illegal fishing in Yeşilırmak estuaries. Decreasing the mortality resulting from fishing is a very important factor in the rehabilitation of the stocks efficiently. An effective program to decrease the incidental capture of the fish to avoid future losses of the few remaining adult fish and juveniles should be established (Anonymous, 2015b). Moreover, a conservation status should be determined for Yeşilırmak estuaries for the long-term preservation of sturgeons.

\section{Fishing Vessel Traffic and Illegal Settlement Problems}

Yeşilırmak estuary is used as relatively low density area for human settlement compared to many other estuaries in Turkey. However, since there is no fishing port around the river mouth, the inner part of the river mouth is used as a fishing port. The increasing use of river mouth as fishing ports and illegal settlement problems are serious threat to Yeşilırmak (Figure 4). Monitoring and control of this situation by authorized institutions and taking necessary precautions are important both in terms of the protection of environment and the future of sturgeons in Yeşilırmak.

\section{Bridges}

A bridge is a structure constructed from wood, stone, steel or reinforced concrete, which is built over obstacles such as a stream, valley, rail or other roadway for the purpose of providing passage 
over the obstacle. Unfortunately, during the design and construction of bridges over rivers, its impacts on river ecosystem, hydrology, geomorphology, sediment transport, fish and wildlife passage/movement and wildlife habitats are usually not consid-

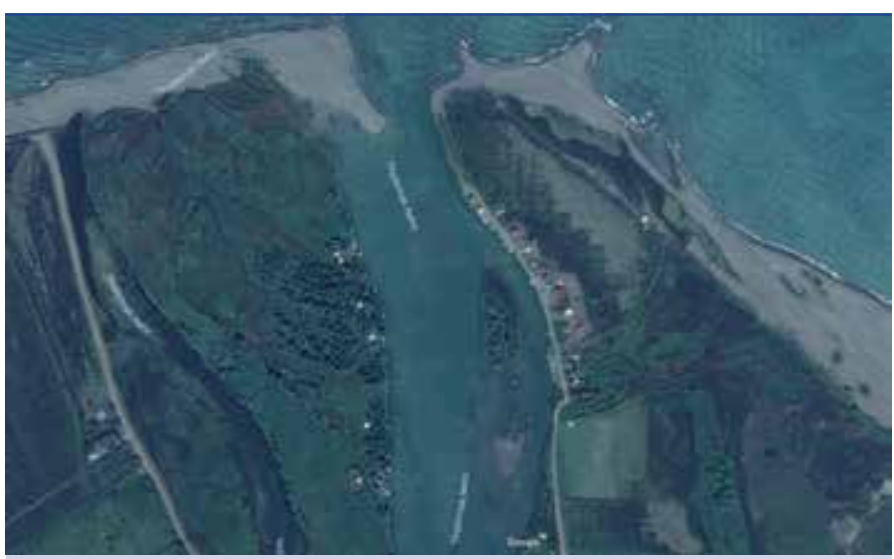

Figure 4. A view from the Yeşilırmak river mouth (Photo: Google Earth, 2018)

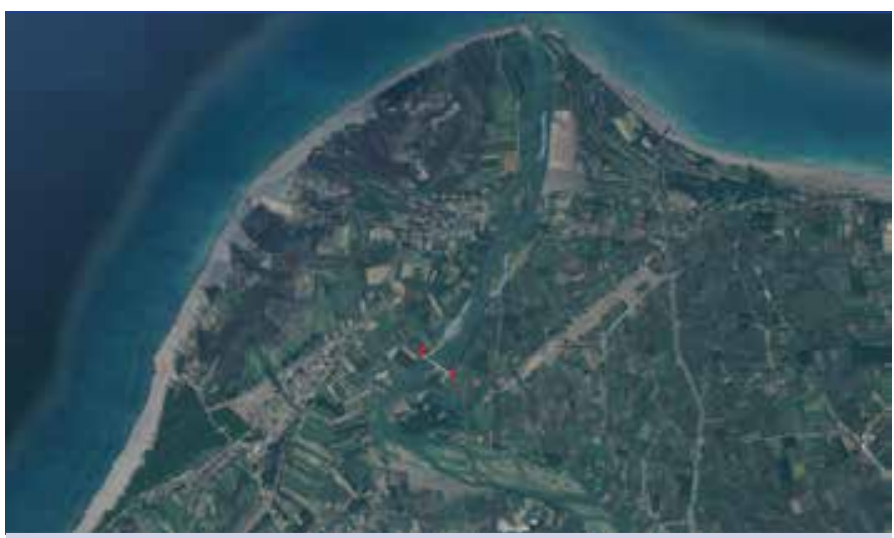

Figure 5. The location of Hürriyet-Kumtepe Bridge on Yeşilırmak (Photo: Google Earth) ered. Bridges may directly result in loss or fragmentation of habitat and increase the disruption of ecosystem processes. Changes of hydrology as a result of bridged crossing can cause alteration in size and section of river geomorphology. Negative impacts on habitat may also occur as a result of bridge maintenance. These impacts are most acute and have long-term effects on fish and wildlife movements (Anonymous, 2008)

There are still 7 reinforced concrete bridges on the section from the river mouth to the first HPP on Yeşilırmak and one bridge is under construction. The bridge, which is the closest to the river mouth (about 4 km) was completed in December 2017 and this bridge is 310 meters long (Figure 5, 6).

Bridge abutments and embankments between them like a dike may affect the movement and passage of sturgeons negatively when water is stored behind the dam or HPP. Therefore, during the design and construction of the bridge the natural life in the river should be considered. The bridges which fully span the watercourse channel provide the best opportunities for maintaining river habitats (Anonymous, 2012). Nevertheless, in the bridges on Yeşilırmak, the natural life in the river has not been considered and critical habitat loss has occurred.

\section{Industrial, Agricultural and Domestic Pollution}

The main sources of pollution in rivers are a discharge of untreated industrial and domestic wastewaters and agricultural activities. Industries and cities have generally been located along rivers because the rivers have been a convenient place to discharge wastes. Besides, agricultural activities have also tended to be concentrated near rivers, because the soil around the rivers is highly fertile.

An intensive agricultural production is carried out in the fertile agricultural lands in the Lower Yeşilırmak Basin and vegetables, fruits and rice are mostly cultivated in Çarşamba Plain. Inorganic fertilizers and pesticides are used intensively for agricultural purposes in the plain. In addition, industrial wastewater (for example from

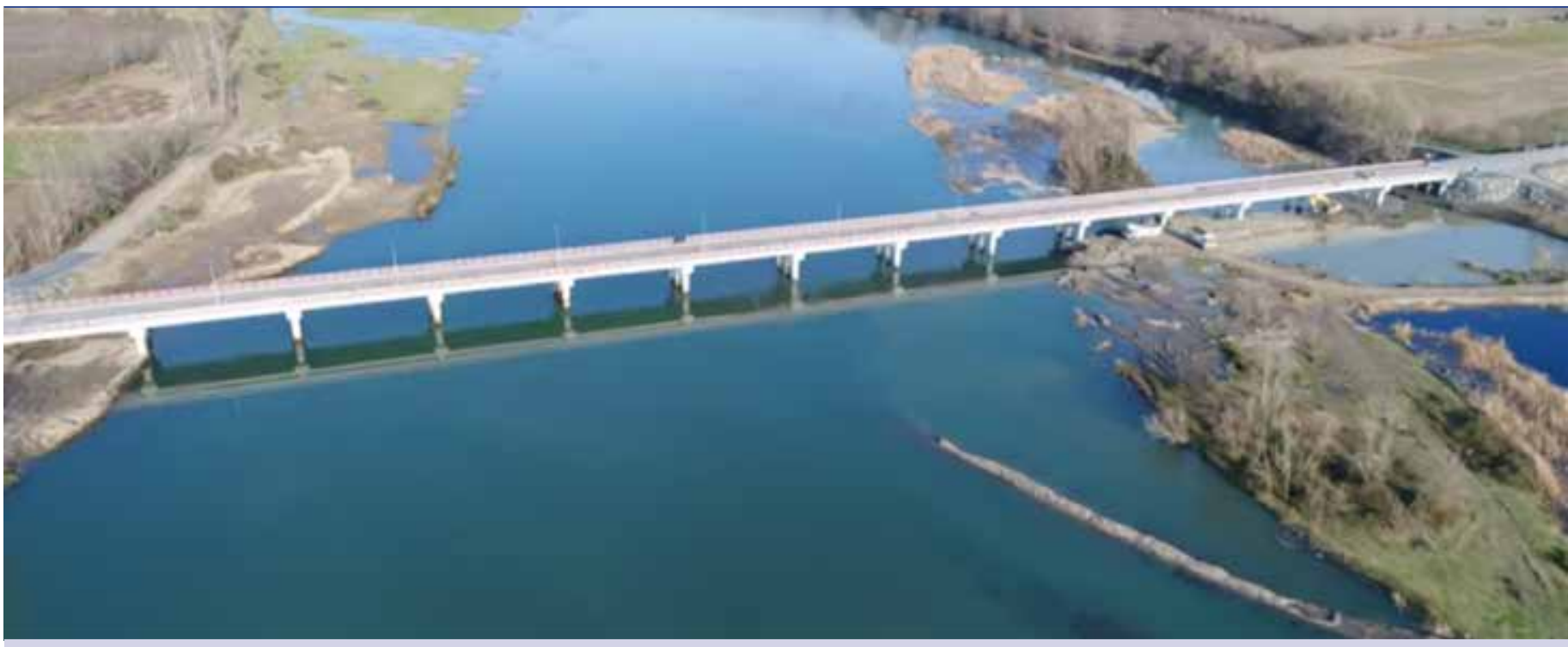

Figure 6. A view of Hürriyet-Kumtepe Bridge on Yeşilırmak (Photo: https://www.youtube.com/watch?v=LB2Xsnu GjZU) 
Çarşamba Sugar Factory) and untreated municipal wastewater also contribute to the pollution in Yeşilırmak. Currently, only 15 of 194 settlements (municipalities and villages) treat their domestic wastewaters in treatment plants in Yeşilırmak Basin (Anonymous, 2015b).

Migratory fish (such as sturgeons and salmonids) have been able to exploit all physically accessible river habitats. Their eggs generally adhere to stones, gravels or weeds. Therefore, fish are sensitive to modification of the river regime (velocity, erosion, etc.) as well as to the input of toxic substances. Consequently, highly specific physical and chemical conditions are necessary in a river for successful breeding. Migratory fish which return from the sea to spawning habitats in upstream stretches of rivers can be prevented from reaching their spawning areas by physical or chemical barriers along their migratory route. Chemical barriers are stretches of highly toxic or anoxic water in the river. The release into rivers of untreated domestic or industrial wastes high in organic matter results in a decline in oxygen concentration (resulting in anoxia) and a release of ammonia and nitrite downstream of the effluent input (Meybeck et al., 1996). All the below mentioned industrial, agricultural and domestic effluents reach the Yeşilırmak but the effects of these inputs on the spawning of sturgeons in the river are unknown. Therefore, the level of pollution impact and the main criteria which are adversely impacted must be identified and the persistence of pollution in the river is to be assessed (Anonymous, 2015b).

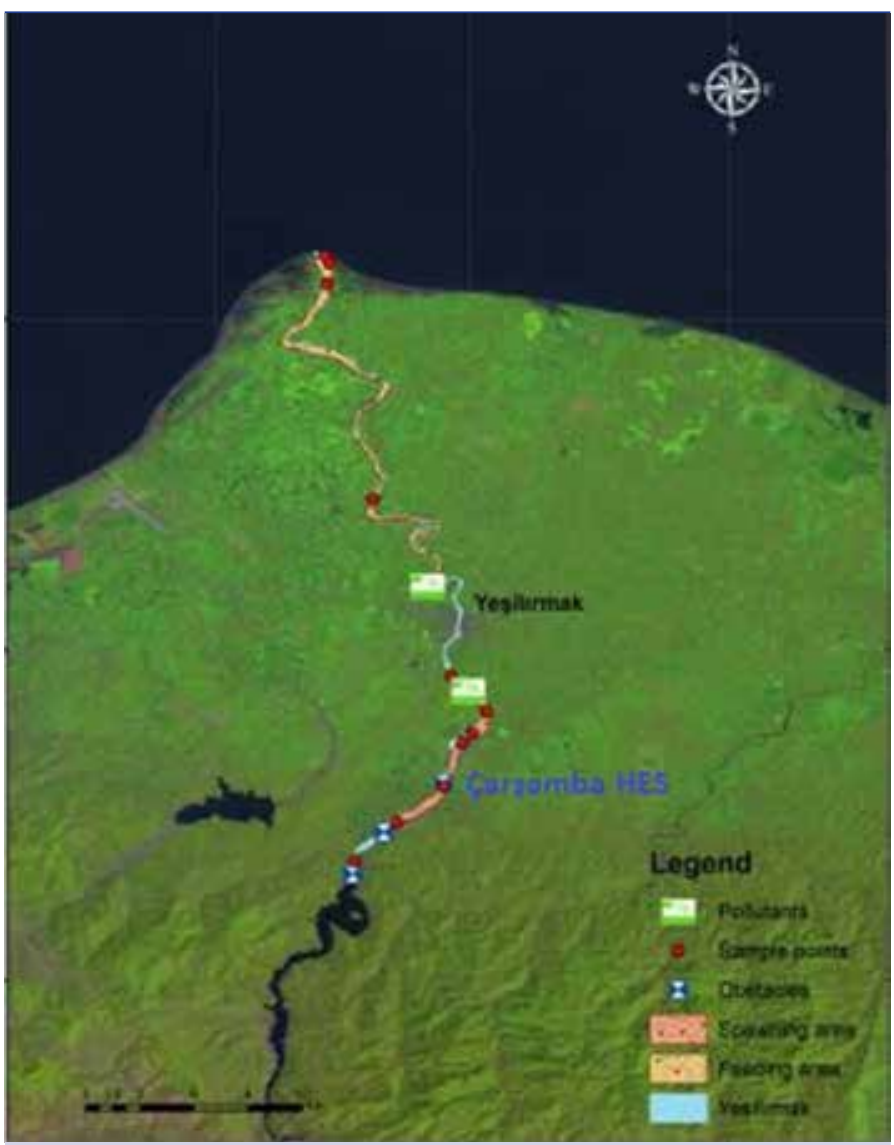

Figure 7. Spawning and feeding areas of sturgeons in Yeşilırmak (Anonymous, 2015b)

\section{CONCLUSION}

Considerable habitat degradation and loss have occurred through dams, HPPs, bridges and river bed modifications in Yeşilırmak. However, it is known, that sturgeons can still migrate upstream into Yeşilırmak and are accidentally caught sometimes in the river mouth or in the river. The information in this regard was reported in the National Action Plan for the Conservation and Restoration of the Sturgeons of Turkey, which prepared within the scope of the project entitled "Recovery of Sturgeon Population in Turkey: Habitat Assessment and Restocking" supported between 2008-2011 by the Food and Agriculture Organization of the United Nations (FAO) and coordinated by the Ministry of Agriculture and Rural Affairs of Turkey (MARA). Moreover, the spawning and feeding areas are identified in the habitat evaluation studies during this project which was given in this National Action Plan (Figure 7).

According to the Action Plan, very limited spawning and feeding areas for sturgeons have remained in Yeşilırmak between the last HPP (Çarşamba HPP) and the river mouth (Figure 7). It is of utmost importance to protect these last remaining areas and to avoid practices that would destroy their habitat. In other words; "last minute" measures are needed urgently. Also it is vital to develop communication tools to increase the awareness of local communities about the conservation value and its role for future rehabilitation measures. It would also be very useful to develop a guarding system in cases where potential poaching might affect the population during migration or reproduction (Anonymous, 2015b).

In conclusion, by evaluating the available historical and current data, it is understood that Yeşilırmak is very important for the future existence of sturgeons in Turkish waters. The still existing/ under construction or planned obstacles in Yeşilırmak (dams, HPPs, bridges, flood control sets, recreational modifications etc.) must be evaluated in detail by the related institutions taking into consideration the National Action Plan.

Conflict of Interest: The authors have no conflicts of interest to declare.

\section{REFERENCES}

Anonymous (2008). Guidelines for Bridge Construction or Maintenance to Accommodate Fish and Wildlife Movement and Passage, Arizona Game and Fish Department, Habitat Branch, USA, 11 pp.

Anonymous (2012). Controlled activities on waterfront land- Guidelines for watercourse crossings on waterfront land. NSW, New South Wales Office of Water, Department of Primary Industries, AU, 4 pp.

Anonymous (2015a). Yeşilırmak Havzası Taşkın Yönetim Planı. Orman ve Su İşleri Bakanlığı Su Yönetimi Genel Müdürlüğü, Rapor, 213 s.

Anonymous (2015b). National Action Plan for the Conservation and Restoration of the Sturgeons of Turkey. Published by The Ministry of Food Agriculture and Livestock, DG Fisheries and Aquaculture, Medisan Yayınevi, Ankara, $127 \mathrm{pp}$

Anonymous (2018a). Available from: https://newredlist.iucnredlist.org/se arch?query=sturgeon\&search Type=species

Anonymous (2018b). Available from: http://www.enerjiatlasi.com/akarsular/yesilirmak.html

Edwards, D., Doroshov, S. (1989). Appraisal of the sturgeon and seatrout fisheries and proposals for a rehabilitation programme. Technical Cooperation Programme, FAO: $37 \mathrm{p}$. 
Gessner, J., Zahn, S., Jaric, I., Wolter, C. (2014). Estimating the potential for habitat restoration and connectivity effects on European sturgeon (Acipenser sturio L. 1758) population rehabilitation in a lowland river - the Havel, Germany. Journal of Applied Ichthyology, 30: 1473-1482. [CrossRef]

Hall, M., Greer, E., Fogarty, M., Barthelmess, E. (2012). Restoration of Declining Lake Sturgeon Populations: A Northern New York Case Study, 58 pp. (Available from: http://www.stlawu.edu/sites/default/ files/resource/LakeSturgeonConservation.pdf)

Hayat Magazine (1969). Haftalık Mecmua, Yıl:14, Sayı:23, Cilt:2, Sıra No:660, Neşriyat A.Ş., İstanbul, 29.05.1969.

Hayes, D.B., Caroffino, D.C. (2012). Michigan's Lake Sturgeon Rehabilitation Strategy. Michigan Department of Natural Resources Fisheries Special Report 62, 18 pp.

Hochleithner, M. (1996). Störe. Verbreitung, Lebensweise, Aquakultur. Österreichischer Agrarverlag, Klosterneuburg, 202 pp.

Kadıoğlu, Y. (2016). Çarşamba Ovası Örneğinde Ekstrem Hava Olaylarının Zirai Faaliyetler Üzerindeki Etkisine Dair Bir Değerlendirme. TÜCAUM Uluslararası Coğrafya Sempozyumu, 13-14 Ekim 2016, Ankara, Bildiri Kitabı, 528-537.

Kirschbaum, F., Gessner, J. (2001). Zur Biologie der Störe. Der Stör Acipenser sturio L., Fisch des Jahres 2001, Verband Deutscher Sportfischer e.V., Verlag M. Faste, 7-14.
McLusky, D.S., Elliot, M. (2011). The estuarine ecosystem: ecology, threats and management. Oxford University Press, Third Edition, $214 p$.

Meybeck, M., Friedrich, G., Thomas, R., Chapman, D. (1996). Rivers. In D. Chapman (Ed.) Water Quality Assessments - A Guide to Use of Biota, Sediments and Water in Environmental Monitoring - Second Edition (pp. 246-324) ISBN 0419215905.

Reichle, G. (1997). Der Stör. Ein gefaehrdeter Urweltfisch im Meer, im Strom und als Nutzfisch in der Teichwirtschaft. Verlag Lassleben Kallmünz: 80 pp.

Ustaoğlu Tırıl, S., Memiş, D. (2013). Mersin Balıklarının Türkiye Sularındaki Durumu. Biyolojik Çeşitlilik Sempozyumu, Muğla Sıtkı Koçman Üniversitesi \& Orman ve Su İşleri Bakanlığı Doğa Koruma ve Milli Parklar Genel Müdürlüğ̈̈, 22-23 Mayıs 2013, Muğla (Bildiri kitabı).

Ustaoğlu Tırıl, S., Memiş, D. (2015). Türkiye Cumhuriyeti'nin İkinci Sanayi Planı (1936)'nda Mersin Balıklarının Yeri ve Önemi. İstanbul Üniversitesi Su Ürünleri Dergisi, 30(2): 21-25.

Zengin, M., Ustaoğlu Tırıl, S. (2012). Tehlike Altındaki Mersin Populasyonlarının Üreme Göçü iç̧in Yeşilırmak Hala Bir Umut Olabilir mi? Türkiye'nin Kıyı ve Deniz Alanları IX. Ulusal Kongresi, 14-17 Kasım 2012, Antakya-Hatay, (Eds: L. BALAS, A.N. GENÇ): 421-434. 